\title{
Cardiac Iron Overload: Correlation between MRI T2* \& Two Dimensional Strain Echocardiography in Children with $\beta$-Thalassemia Major
}

\author{
DINA Sh.M. MANAA, M.Sc.*; MOHAMMED R. EL-SHANSHORY, M.D.*, \\ OSAMA ABD RAB EL-RASSOL, M.D. and RASHA A. EL-SHAFEY, M.D.** \\ The Departments of Pediatrics* and Diagnostic Radiology**, Faculty of Medicine, Tanta University
}

\begin{abstract}
Background: $\beta$-thalassemia is a group of inherited blood disorders that causes iron overload in the heart. Development of overt heart failure is delayed till the second decade of life. Early detection of cardiac iron overload is necessary before development of heart failure.
\end{abstract}

Aim of the Study: Was to evaluate cardiac function in children with $\beta$-thalassemia major having iron overload and to Compare MRI T2* and doppler echocardiography in demonstration of iron deposition in cardiac muscles in those patients.

Patients and Methods: Fifty children with thalassemia major were subjected to history taking, clinical assessment, laboratory assessment, Doppler echocardiography and MRI for cardiac iron load assessment.

Results: There is a negative correlation between cardiac MRI T2* with age, ferritin and serum iron level. As regard correltion between MRI and doppler echocardiography there is a positive correlation between MRI T2* and diastolic echocardiographic parameters Tei index in patients with thalassemia Major.

Conclusion: There is a significant correlation between MRI T2* and Doppler echocardiography in patients with $\beta$ thalassemia major.

Key Words: $\beta$-thalassemia major - MRI T2*-2D echocardiography-Cardiac iron overload.

\section{Introduction}

THALASSEMIA is an Inherited hemoglobinrelated disorder which affects more than 300,000 children annually, particularly in malaria-endemic regions stretching from sub-Saharan Africa and the Mediterranean to Southeast Asia, Early clinical recognition of these disorders is essential [1] .

Correspondence to: Dr. Dina Sh.M. Manaa, The Department of Pediatrics, Faculty of Medicine, Tanta University
Iron overload is an important clinical challenge in patients with thalassemia. It occurs primarily as a result of increased intestinal iron absorption but also can result from blood transfusion therapy [2].

Life expectancy in patients with thalassaemia major is still limited by development of congestive heart failure due to a cardiomyopathy associated with iron over-load [3].

Echocardiography is a useful and noninvasive diagnostic tool for diagnosis of heart disorders and helps with early detection of heart failure before the development of symptoms. Therefore, serial echocardiography is recommended in asymptomatic patients with $\beta$-thalassemia for early diagnosis of heart dysfunction [4].

2D strain analysis technique is a new method for assessment of myocardial function. It offers many advantages as it is less time-consuming, angle independent, can assess strain in 3 dimensions (longitudinal, circumferential, and radial), semiautomated and gives information about global as well as segmental systolic strain [5].

Magnetic resonance imaging (MRI) by the $\mathrm{T} 2 *$ technique: Allows highly reproducible and noninvasive quantifications of myocardial iron burden. Moreover, MRI is the gold standard for quantifying biventricular function parameters [6]

Aim: To evaluate cardiac function in children with $\beta$-thalassemia major having iron overload and to compare MRI T2* and Doppler echocardiography in demonstration of iron deposition in cardiac muscles in those patients. 


\section{Patients and Methods}

This study was carried out upon 50 patients with $\beta$-Thalassemic. These thalassemic children were selected from patients admitted to Heamatology unit, pediatric department, Tanta University Hospital during the period from October 2016 to October 2017, and 20 healthy children served as a control group.

\section{All patients were subjected to:}

A- Full history taking and thorough clinical examination.

$B$ - Investigations: Complete blood picture. Iron profile (serum iron - ferritin - total iron binding capacity)

C- Cardiac iron concentration measurement: By MRI and two dimensional strain of echocardiography.
Statistical presentation and analysis of the present study was conducted using the mean, standard deviation, student $t$-test, Chi-square by SPSS V20 with $p<0.05$ means significance.

\section{Results}

This study was carried out upon 70 children (50 patients and 20 control).

Table (1) show that there was statistically significant difference between the patients and the control groups as regard MPI, EF, SPI, L, C, A and R. ( $p$-value $<0.05)$. MPI, EF, L, C, A and R increased in control groups than patients groups while SPI decreased in patients than control groups. There was no statistically significant difference between the patients and the studied groups as regard $\mathrm{S},(\grave{\mathrm{E}} / \hat{\mathrm{A}})$ and 2DS ( $p$-value $>0.05$.

Table (1): Comparison between the studied groups as regard echocardiographic parameters.

\begin{tabular}{|c|c|c|c|c|c|}
\hline & & \multicolumn{2}{|c|}{ Groups } & \multicolumn{2}{|c|}{$t$-test } \\
\hline & & Patients & Controls & $t$ & $p$-value \\
\hline \multirow[t]{2}{*}{ Echo $\mathrm{S} \mathrm{cm} / \mathrm{s}$} & Range & $5-8$ & $5-9$ & -0.041 & 0.967 \\
\hline & Mean \pm SD & $6.840 \pm 0.842$ & $6.850 \pm 1.089$ & & \\
\hline \multirow[t]{2}{*}{ Echo È/À ratio } & Range & $0.7-2.4$ & $1.2-2.4$ & -0.784 & 0.436 \\
\hline & Mean \pm SD & $1.564 \pm 0.448$ & $1.650 \pm 0.312$ & & \\
\hline \multirow[t]{2}{*}{ Echo MPI } & Range & $0.33-0.73$ & $0.53-0.74$ & -5.034 & $<0.001 *$ \\
\hline & Mean $\pm \mathrm{SD}$ & $0.484 \pm 0.099$ & $0.608 \pm 0.077$ & & \\
\hline \multirow[t]{2}{*}{ Echo 2DS (\%) } & Range & $-26--17$ & $-25--20$ & 1.581 & 0.119 \\
\hline & Mean $\pm \mathrm{SD}$ & $-21.280-2.483$ & $-22.250 \pm 1.832$ & & \\
\hline \multirow[t]{2}{*}{ Echo EF (\%) } & Range & $23-73$ & $50-75$ & -2.330 & $0.023^{*}$ \\
\hline & Mean \pm SD & $53.280 \pm 13.067$ & $60.600 \pm 8.009$ & & \\
\hline \multirow[t]{2}{*}{ Echo SPI } & Range & $0.21-0.87$ & $0.31-0.59$ & 2.754 & $0.008^{*}$ \\
\hline & Mean $\pm \mathrm{SD}$ & $0.560 \pm 0.173$ & $0.448 \pm 0.093$ & & \\
\hline \multirow[t]{2}{*}{ Echo L (\%) } & Range & $-30--5$ & $-22--17$ & 2.389 & $0.020 *$ \\
\hline & Mean $\pm \mathrm{SD}$ & $-16.000 \pm 5.707$ & $-19.100 \pm 1.447$ & & \\
\hline \multirow[t]{2}{*}{ Echo C (\%) } & Range & $-25--2$ & $-20--15$ & 5.811 & $<0.001 *$ \\
\hline & Mean \pm SD & $-9.080 \pm 5.314$ & $-16.100 \pm 1.334$ & & \\
\hline \multirow[t]{2}{*}{ Echo A (\%) } & Range & $-29--10$ & $-28--21$ & 2.465 & $0.016^{*}$ \\
\hline & Mean \pm SD & $-19.720 \pm 6.037$ & $-23.150 \pm 2.231$ & & \\
\hline \multirow[t]{2}{*}{ Echo R (\%) } & Range & $10-50$ & $30-45$ & -2.028 & $0.047 *$ \\
\hline & Mean \pm SD & $31.680 \pm 10.994$ & $36.850 \pm 4.545$ & & \\
\hline $\begin{array}{l:}\text { MPI } \\
\text { EDS } \\
\mathrm{EF}\end{array}$ & $\begin{array}{l}\text { nulus systolic } \\
\text { ial performac } \\
\text { ional strain. } \\
\text { Fraction. }\end{array}$ & & $\begin{array}{ll}\text { SPI } & \text { Stroke power ir } \\
\text { LS } & : \text { Longitudinal st } \\
\text { CS } & : \text { Circumferentia } \\
\text { AS } & \text { : Area strain. } \\
\text { RS } & \text { : Radial strain. }\end{array}$ & $\begin{array}{l}\text { ex or sphe } \\
\text { n. } \\
\text { rain. }\end{array}$ & \\
\hline
\end{tabular}


Table (2) show that there was negative correlation between cardiac MRI T2* with MRI R2 ( $p$ value $<0.05)$. There was also negative correlation between cardiac MRI T2* with age ( $p$-value $<0.05$ ). There was negative correlation between cardiac MRI T2* with serum ferritin level ( $p$-value <0.05). There was negative correlation between cardiac MRI T2* with serum iron level ( $p$-value $<0.05$ ). There was positive correlation between cardiac MRI T2* with TIBC ( $p$-value $<0.05$ ), also there was positive correlation between cardiac MRI T2* with Echo MPI ( $p$-value <0.05). There was positive correlation between cardiac MRI R2 with iron level ( $p$-value $<0.05)$. There was negative correlation between cardiac MRI R2 with TIBC ( $p$-value $<0.05$ ). There was no correlation between MRI T2* with weight, height, BMI, HB, platelets, TLC, Echo S, Echo Ė/À, Echo 2DS, Echo EF, Echo SPI, Echo L, Echo C, Echo A and Echo R. ( $p$-value $>0.05)$. There was no correlation between MRI R2 with weight, height, BMI, HB, platelets,TLC, ferritin, Echo S, Echo È/À, Echo MPI, Echo 2DS, Echo EF, Echo SPI, Echo L, Echo C, Echo A and Echo $\mathrm{R}$ ( $p$-value $>0.05)$.

Table (2): Correlations between cardiac MRI T2* and MRI R2 with age, weight, height, BMI, complete blood count, Iron profile and different echocardiographic parameters.

\begin{tabular}{|c|c|c|c|c|}
\hline & \multicolumn{4}{|c|}{ Correlations } \\
\hline & \multicolumn{2}{|c|}{ MRI T2 } & \multicolumn{2}{|c|}{ MRI R2 } \\
\hline & $r$ & $p$-value & $r$ & $p$-value \\
\hline MRI R2 & -0.646 & $<0.001 *$ & & \\
\hline Age (years) & -0.285 & $0.045^{*}$ & 0.238 & 0.096 \\
\hline Weight (Kg) & -0.068 & 0.640 & 0.210 & 0.143 \\
\hline Height (Cm) & -0.016 & 0.915 & 0.147 & 0.307 \\
\hline BMI $(\%)$ & -0.226 & 0.115 & 0.232 & 0.105 \\
\hline $\mathrm{HB}(\mathrm{gm} / \mathrm{dl})$ & 0.238 & 0.096 & -0.163 & 0.259 \\
\hline Platelet $\left(\mathrm{X} 10^{3} / \mathrm{cm}^{3}\right)$ & 0.006 & 0.965 & -0.079 & 0.587 \\
\hline $\operatorname{TLC}\left(\mathrm{X} 10^{3} / \mathrm{cm}\right)$ & -0.076 & 0.602 & -0.033 & 0.820 \\
\hline Ferritin (ng/ml) & -0.361 & $0.010^{*}$ & 0.268 & 0.060 \\
\hline Iron (ng/ml) & -0.495 & $<0.001 *$ & 0.442 & $0.001 *$ \\
\hline TIBC (ng/ml) & 0.451 & $0.001 *$ & -0.422 & $0.002 *$ \\
\hline Echo $S(\mathrm{~cm} / \mathrm{s})$ & 0.047 & 0.744 & 0.069 & 0.632 \\
\hline Echo E/A ratio & 0.151 & 0.294 & -0.105 & 0.467 \\
\hline Echo MPI & 0.487 & $<0.001 *$ & -0.139 & 0.336 \\
\hline Echo 2DS (\%) & -0.189 & 0.189 & 0.025 & 0.863 \\
\hline Echo EF (\%) & 0.163 & 0.258 & -0.254 & 0.075 \\
\hline Echo SPI & -0.219 & 0.127 & 0.088 & 0.542 \\
\hline Echo L (\%) & -0.178 & 0.216 & -0.067 & 0.645 \\
\hline Echo C (\%) & -0.104 & 0.474 & -0.090 & 0.536 \\
\hline Echo A (\%) & 0.027 & 0.855 & -0.095 & 0.511 \\
\hline Echo R (\%) & 0.048 & 0.739 & 0.047 & 0.744 \\
\hline
\end{tabular}

\section{Discussion}

This study showed that the mean of ejection fraction (EF) of children with thalassemia was significantly lower than the control group. This means that these children suffered from left ventricular systolic dysfunction, which was in accordance to the study of (Abdelmoktader et al., 2013) who reported at their study of the value of pulsed tissue Doppler imaging in early detection of left ventricular dysfunction in asymptomatic children with beta thalassemia that EF was significantly lower in patients with thalassemia than control.

This study also showed that there was significant increase in stroke power index or sphericity index (SPI) in patients than the control group. SPI is a sensitive parameter for detecting left ventricular remodeling which develop early before the development of cardiomyopathy, that's why it is affected earlier than other parameters.

This study showed that mean MPI of patients with thalassemia was higher than the control group with high significant difference between both groups which means that left ventricular systolic and diastolic functions of the studied group of patients with thalassemia was affected without showing any symptom of heart failure. This was in accordance with the study of Uçar et al., [8] who reported that mean MPI of patients with thalassemia 
was significantly higher than that of control group and concluded that MPI taken by tissue Doppler imaging (TDI) can be an early parameter for early detection of left ventricular dysfunction.

In this study, as regard other TDI parameters; $\mathrm{S}$ and $\mathrm{E}^{\prime} / \mathrm{A}^{\prime}$ ratio, there were no statistically significant difference between both groups.

Also, there was a significantly lower longitudinal strain (LS) in patients with thalassemia compared to controls which means that there were left ventricular dysfunction in those thalassemia patients without any cardiac symptoms.

Monte et al., [9] agreed with us as their patients with thalassemia showed significantly low LS if compared to controls.

Regarding this study there were highly significant difference between both groups as regard circumferential strain (CS) which means that there was left ventricular dysfunction in patients with thalassemia without any cardiac symptoms.

Monte et al., [9] agreed with us as their patients with thalassemia showed significantly low CS if compared to controls.

In this study there was a highly significant low radial strain (RS) in patients with thalassemia than control which means that there were left ventricular dysfunction in patients with thalassemia without any cardiac symptoms.

Monte et al., [9] agreed with us as their studied patients with thalassemia showed significantly low $\mathrm{RS}$ if compared to controls.

There was a highly significant low area strain (AS) in patients with thalassemia than the control group in this study, which means that there was left ventricular dysfunction concerning the subendocardial surface of patients with thalassemia without any cardiac symptoms. Also, this study showed that there was a highly significant correlation between AS and EF. Li et al., [10] agreed with our results concerning area strain and also showed higher correlation with LVEF which coincide with our results.

Felix Liauw et al., [11] categorized cardiac T2* as severe $(\mathrm{T} 2 *<10 \mathrm{~ms})$, moderate $(10<\mathrm{T} 2 *<14 \mathrm{~ms})$, mild $(14<\mathrm{T} 2 *<20 \mathrm{~ms})$, and acceptable $(\mathrm{T} 2 *>20 \mathrm{~ms})$.

In this study, we found that $\mathrm{T} 2 *$ ranged from $2.8-109 \mathrm{~ms}$. Normal cases were 32 with $\mathrm{T} 2 *$ ranging from 25-109ms. Mild cases were 4 with T2* ranging from 12.6-18.8ms. Moderate cases were 6 with T2* ranging from $9.4-11.7 \mathrm{~ms}$. Severe cases were 8 with $\mathrm{T} 2 *$ ranging from $2.8-5.5 \mathrm{~ms}$.

Also this study showed that there was a negative correlation between MRI T2* values with age. This is in agreement with Oliveri NF, Brittenham GM. 2007 who demonstrated that when age is increasing the level of iron is increased in patients with thalassemia.

It is currently accepted that MR relaxometry is the method of choice for non-invasive and accurate measurement of iron load. (MAVROGENI et al., 2011). The data can be obtained in a single breath hold. Myocardial iron overload causes decrease of values of $\mathrm{T} 2 *$ because iron interferes with local magnetic field homogeneity [14].

Decreasing cardiac $\mathrm{T} 2 *$ values correspond with increasing levels of cardiac iron and increasing risk of cardiac dysfunction [15]

Iron, typically in the form of ferritin and hemosiderin, shortens the relaxation times $\mathrm{T} 2 *, \mathrm{~T} 2$, and $\mathrm{T} 1$, and increases the relaxation rates $\mathrm{R} 2 *, \mathrm{R} 2$, and R1. (Hernando et al., 2014).

Also this study showed that MRI T2* is inversely proportional to ferritin level, while MRI R2 is directly proportional to ferritin level.

This study showed that there was a positive correlation between MRI T2* results and Tei index in patients with thalassemia. This result was in agreement with AESSOPOS et al., [17] . As Tei index is independent of arterial pressure, heart rate, ventricular geometry, atrioventricular valvular regurgitation, and pre-and after load so it is a sensitive modality for detection of cardiac affection.

The present study showed that there was no correlation between other echocardiographic parameters and MRI T2* value. These findings agreed with Karan et al., [18] who found that the correlation was not strong, and the echo parameters showed low sensitivity.

This study showed that, there was no correlation between serum ferritin level with any of echocardiographic parameters. This agrees with Mavrogeni et al., [19] who found a poor correlation between iron load and ventricular function, but this may reflect the inadequacy of serum ferritin levels or the number of blood transfusions as predictors of myocardial iron status. 


\section{Conclusion:}

There is a good correlation between cardiac MRI T2* and Tei index in detection of cardiac affection in patients with thalassemia.

\section{Acknowledgments:}

This research was carried out without funding.

Conflicts of interest:

No conflicts of interest declared.

\section{Authors' Contributions:}

All authors had equal role in design, work, statistical analysis and manuscript writing. All authors have approved the final article work.

\section{References}

1- WEATHERALL D.J.: Phenotype-genotype relationships in monogenic disease: Lessons from the thalassemias. Nat. Rev. Genet., 2: 245-255, 2001.

2- MUSALLAM K.M., SANKARAN V.G., CAPPELLINI M.D., et al.: Fetal hemoglobin levels and morbidity in untransfused patients with $\beta$-thalassemia intermedia. Blood., 119: 364-367, 2012.

3- HOFIBFAND A.V.: Diagnosing myocardial iron overload. Eur. Heart. J., 2: 2140-2141, 2001.

4- NOORI N.M. and MEHRALIZADEH S.: Echocardiographic evaluation of systolic and diastolic heart function in patients suffering from beta-thalassemia major aged 5-10 years at the Zahedan Research Center for Children and Adolescent Health. Anatol. J. Cardiol., 2 (10): 150153,2010

5- KNEBEL F., SCHATTKE S., BONDKE H., et al.: Evaluation of longitudinal and radial two-dimensional strain imaging versus Doppler tissue chocardiography in predicting long-term response to cardiac resynchronizationtherapy. J. Am. Soc. Echocardiogr., 20 (4): 335-341, 2007.

6- PATHARE A., TAHERA and DAARS.: Deferasirox [Exjade (R)] significantly improves cardiac $\mathrm{T} 2 *$ in heavily iron-overloaded patients with $\beta$-thalassemia Major. Ann. Hemato., 189 (4): 405-409, 2010.

7- ABDELMOKTADER A.M. and AZER H.Y.: Usefulness of pulsed wave tissue doppler imaging in assessment of left ventricular functions in children with bethalassemia major. Indian. J. Pediatr. Sep., 80: 721-725, 2013.
8- UÇAR T., ILERI T., ATALAY S., et al.: Early detection of myocardial dysfunction in children with betathalassaemia major. Int. J. Cardiovasc. Imaging, 25: 379386, 2009 .

9- MONTE I., BUCCHERI S., BOTTAR V., et al.: Left ventricular rotational dynamics in Beta thalassemia major: A speckle-tracking echocardiographic study. J. Am. Soc. Echocardiogr., 25: 1083-1090, 2012.

10- LI S.J., HWANG Y.Y., HA, S.Y., et al.: Role of ThreeDimensional Speckle Tracking Echocardiography in the Quantification of Myocardial Iron Overload in Patients with Beta-Thalassemia Major. Echocardiography, 1-7, 2016.

11- FELIX LIAUW, DAMAYANTI SEKARSARI, SITI AYU PUTRIASIH, et al.: Evaluation of cardiac and hepatic iron overload in thalassemia major patients with $\mathrm{T} 2$ * magnetic resonance imaging. Official journal of the International Society of Hematology, 22: 501-507, 2017.

12- OLIVIERI N.F. and BRITTENHAM G.M.: Iron-chelating therapy and the treatment of thalassemia. Blood, 89: 739$761,2007$.

13- MAVROGENI S., PEPE A. and LOMBARDI M.: Evaluation of myocardial iron overload using cardiovascular magnetic resonance imaging. Hellenic. J. Cardiol., 52: 385-390, 2011.

14- ARGYROPOULOU M.I. and ASTRAKAS L.: MRI evaluation of tissue iron burden in patients with betathalassaemia major. Pediatr. Radiol., 37: 1191-1200, 2007.

15- KIRK P., ROUGHTON M., PORTER J.B., et al.: Cardiac $\mathrm{T} 2 *$ magnetic resonance for prediction of cardiac complications in thalassemia Major. Circulation., 120: 19611968, 2009.

16- HERNANDO D., LEVIN Y.S., SIRLIN C.B., et al.: Quantification of liver iron with MRI: state of the art and remaining challenges. J. Magn. Reson. Imaging, 40: 1003$21,2014$.

17- ASSEOPOS A., FARMAKIS D., DEFTEREOS S., et al.: Thalassemia heart disease: A comparative evaluation of thalassemia Major and thalassemia intermedia. Chest., 127: 1523-1530, 2005.

18- KARAN B., OZBEK O., ACAR K., KAYRAK M., OZBEK S., GUL E.E., UCAR R. and PAKSOY Y.: Relationship between color M-mode echocardiography flow propagation and cardiac iron load on MRI in patients with thalassemia major. Diagn. Interv. Radiol. Oct., 17, 2011.

19- MAVROGENI S.I., GOTIS E.D., MARKUSSIS V., et al.: T 2 relaxation time study of iron overload in $\mathrm{P}$-thalassemia. MAGMA., 6: 7-12, 1998. 


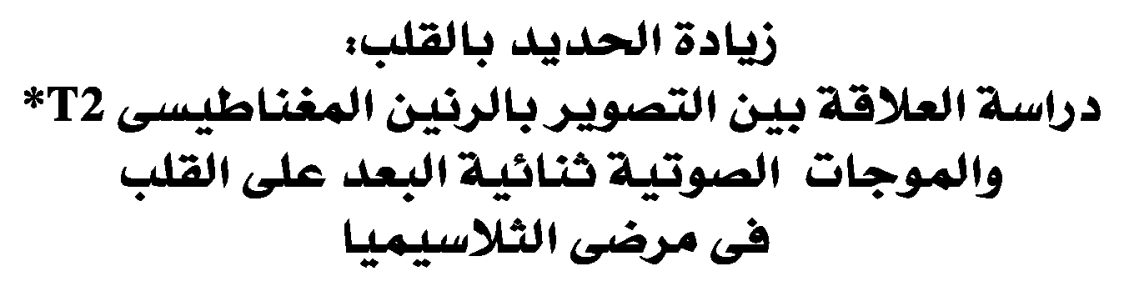

تعد أنيميا البحر المتوسط واحدة من الأمراض الوراثية التى تسبب تراكم الصديد بالقلب.

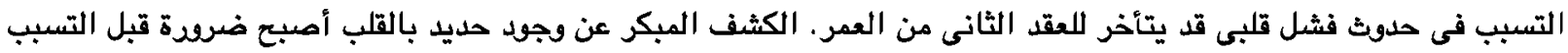

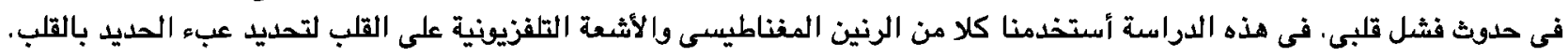

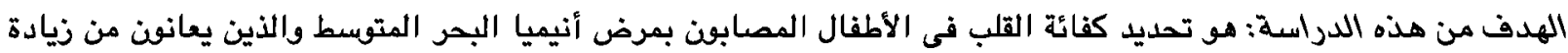
عبء الحديد والمقا رنة بين الرنين المغناطيسى والأشعة التلفزيونية على القلب فى تحديد زيادة الحديد بعضلات العات القلب في هؤلاء الأطفال.

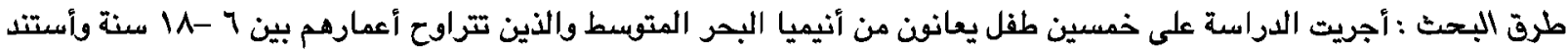

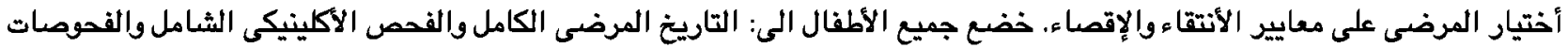
المعملية أشعة تلفزيونية على القلب ودنين مغناطيسى على الأنقيس القلب.

النتائج: تم إيجاد علاقة إحصائية عكسية ذات دلالة بين الرنين المغناطيسى على القلب والعمر ونسبة الحديد والفريتين في البلازما

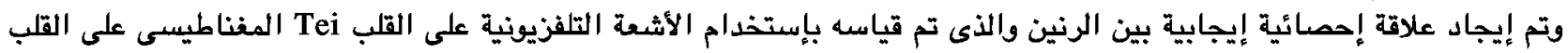
ومعامل فى وقت الأسترخاء.

الأستتاج: هناك علا قة طردية بين نتائج الرنين المغناطيسى و الأشعة التلفزيونية على القلب فى الأطفال المصابين بمرض أنيميا البحر المتوسط. التوصيات: نوصى بعمل المزيد من الأبحاث بإستخدام الأشعة التلفزيونية الثُاثية البعد على القلب والرنين المغناطيسى على القلب. 